\title{
North Gondwanan Emsian events
}

\author{
Departamento de Gerlogía, Universidad de Oviedo. 33005 Oviedo. Spain
}

On the basis of lithostratigraphic and biostratigraphic characteristics three Emsian events, first noted in the Caech Republic, have been distinguished in the north Gondwanct regions of Spain and adjoining areas. These events, the Basal Zlichov Event (BZE), the Upper Zli(hov Event (UZE) and the Daleje-Cancellata Event (DCE) are keystones in the Emsian stratigraphy in that they allow to deal with problems of stage and substage definition from a different all-embracing approach.

\section{Introduction}

During the Devonian the Iberian Peninsula and adjoining areas (Armorican Massif. Morocco) belonged to the northern part of the Gondwana continent (Mauro-Ibero-Armorican Province, Carls, 1988). This large paleogeographical unit was separated from the other great super-continent of the period, Euroamerica, by a seaway, the Rheic occan. The extent of this seaway has been extensively discussed but is no longer considered to have prevented faunal exchange among the bordering continents. Abundant paleontological and stratigraphical information concerning the North Gondwana Devonian stress the rather strong similarity with Euroamerica (García-Alcalde. 1995) especially since the Late Emsian. Nevertheless, the connections between both continents began earlier as can be noticed from the ease with which it is possible to discriminate in North Gondwana Lower Emsian events first noted and described in Euroamerica (Czech Republic).

In this paper three Emsian events, the Basal Zlichov, the Upper Zlichov, and the Daleje-Cancellata, are identified in North Gondwana. and their lithologic and paleontologic features are analyzed in the different areas with special emphasis on those of the Cantabrian region (northern Spain).

\section{Basal Zlichov Event (BZE)}

The Basal Zlichov Event (BZE), has been characterized in Bohemia (Czech Republic) as a minor, rather local, and tectonically-controlled event. with slight faunal overturn and very varied lithologic changes matching different geological processes, both transgressive and regressive even in the same basin (Chlupač and Kukal, 1986; 1988).

Despite this assertion, the BZE seems a distinct and readily traceable event far from Bohemia, in off-shore or mixed facies, and even in near-shore facies by means of more or less indirect correlations.

In Spain the BZE would be represented everywhere by a clearcut lithologic transition due usually to a transgressive pulse of supraregional influence belonging to Johnson et al.'s (1985) T-R cycle Ib (Ib2, herein, Figure 2).

In the Palentine Domain (Figure 1), the lower part of the Abadía Fm. (Figure 2) consists of about $30 \mathrm{~m}$ of dark grey, micaceous and silty shales. At $20 \mathrm{~m}$. above the base of the Formation, Nowakia zlichovensis uccurs: $7 \mathrm{~m}$. above this level, commences $8 \mathrm{~m}$ of dark grey mudstones. wackestones, and bioclastic packstones, with hummocky cross bedding interbedded with very fossiliferous calcareous siltstones. These beds could represent the BZE in the region occurring at the Polygnathus dehiscens Zone (Nowakia -lichowensis Zone) (García-Alcalde, et al., 1990, text-figure 5). There. for the first time in the Devonian, very abundant and diverse trilonite faunas occur. These faunas are of mixed Bohemian oftshore and Rhenish nearshore character, with species of proetid, aulacopleurid, harpids, cheirurids, and scutelluids, and other forms of the Reedops-Odontochile Assemblage, especially Spinodontochile spinifera. Devonodontochile mccoyi, Odontochile seillouensis, Reedops cf. sternbergi, and other phacopids, homalonotids and asteropyginids (Zone $\mathrm{V}$ of Smeenk, 1983; García-Alcalde, et al., 1990). Several of the innovations cited by Chlupac (1994) as characteristic for the BZE, in particular, the first appearance of true Kayserops, and of new species of Pilletina and other Asteropyginae, are also recognized there $(K$. ogivalis, $P$. aulnensis). At the same levels occur abundant tabulate (Cleistodictyum porosum, Procterodictrum polentinoi, and other pleurodictyids) and rugose corals constituting the most diverse Lower Devonian "Cyathaxonia Fauna" known worldwide (Soto and Kullmann, 1996). Trace fossils, e.g. Chondrites and Zoophross cover the bottom of the beds. Brachiopods are scarce. of low diver-

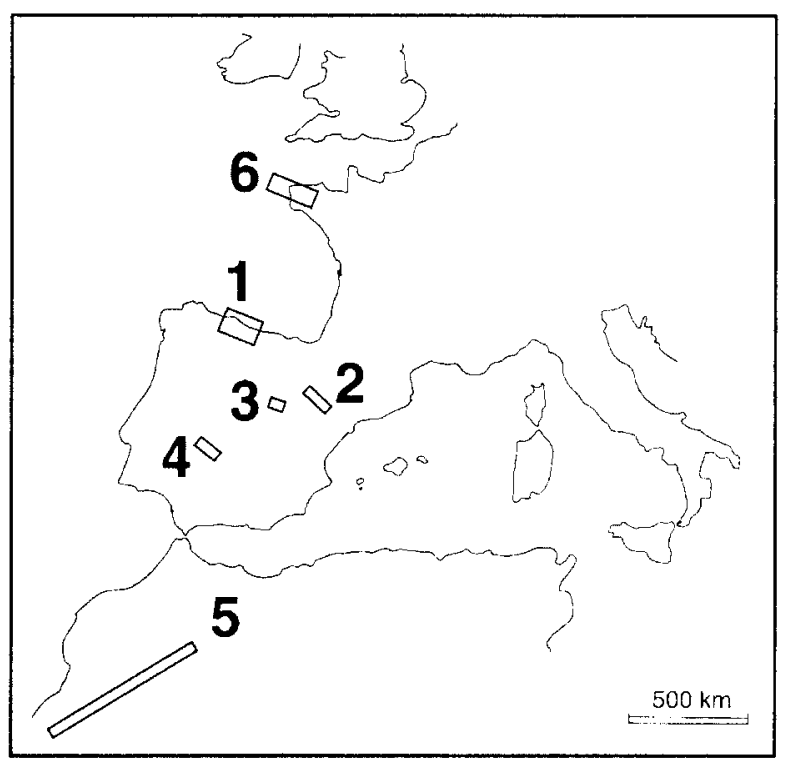

Figure 1 Geographical situation of the discussed regions. 1: Cantabrian Mountains (Asturo-Leonian Domain and Palentine Domain, Spain); 2: Eastern Iberian Chains (Spain); 3: Eastern Guadarrama (Spain); 4: Almadén region (Central Iberian Zone, Spain); 5: Anti-Atlas (Morocco); 6: Rade of Brest (Armorican Massif, France)

sity, and of mixed Bohemian-Rhenish affinities, with Dalejodiscus spp., Prokopia sp., Rugoleptaena sp.. Philippotia belairensis, Plicanoplia carlsi, Xana bubo, and Bifida lepida, Arduspirifer. Euryspirifer of the pellicoi-group and Acrospirifer fallax have also been found there (Jahnke, et al., 1983; and unpublished data).

In the Asturo-Leonian Domain, the base of the La Ladrona Fm. and correlative Formations (Figure 2), display lithologic characters of the BZE, with a marked change from intertidal Bañugues or 


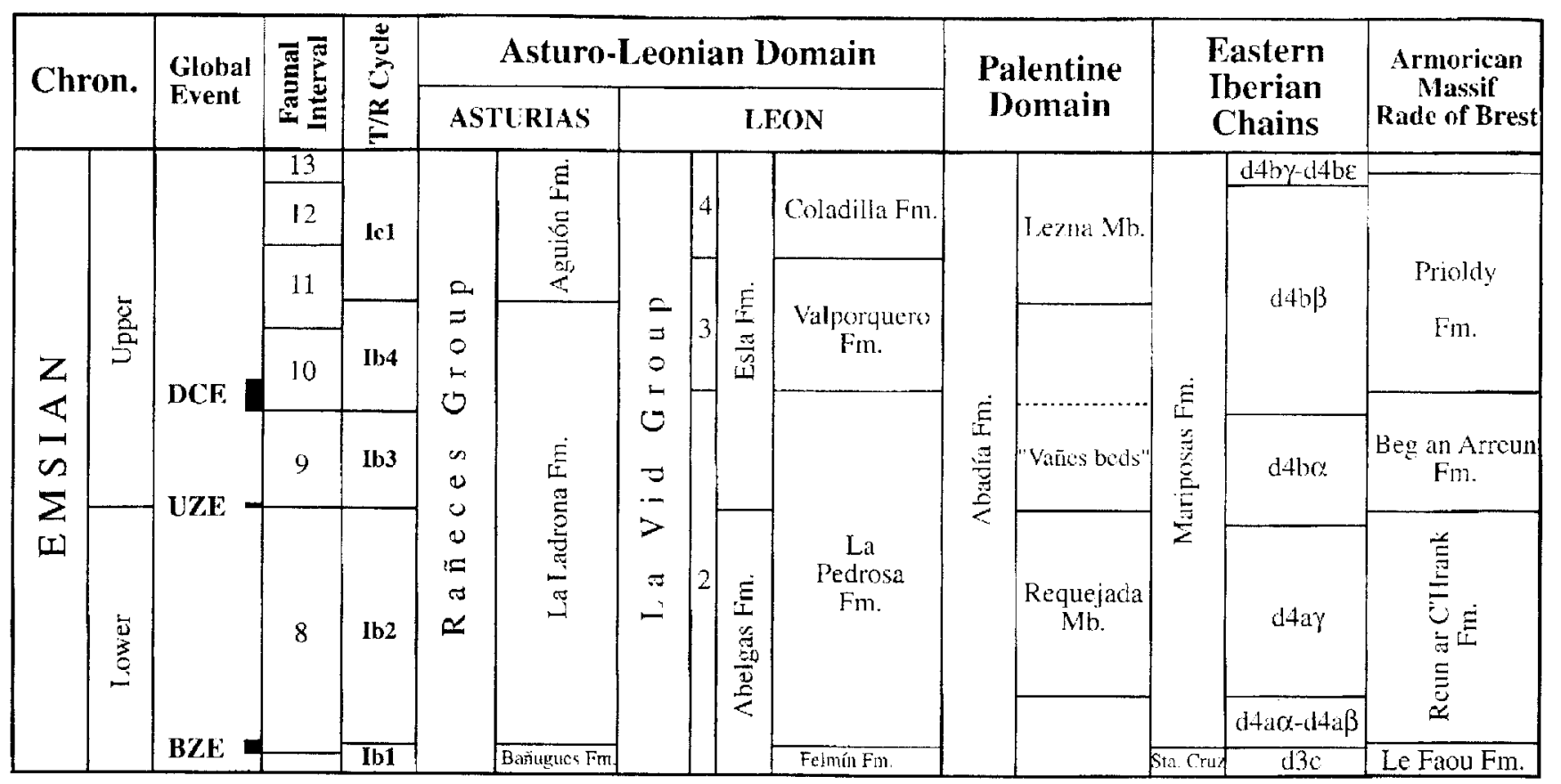

Figure 2 Stratigraphical situation of the global events studied herein in the Cantabrian Mountains (Asturo-Leonian Domain and Palentine Domain), Eastern Iberian Chains, and in the Armorican Massif (Rade de Brest, France). Faunal Intervals: modified from García-Alcalde (1996). T/R Cycles: After Johnson et al. (1985).

Felmin Fms. dolomites to open marine shales and limestones. The transition beds contain abundant Zoophycos and Chondrites and belong to the Polygnathus dehiscens Zone, according to Grötsch (1988; text-figure 3). In these beds, brachiopods of the basal part of "Faunal Interval 8" (García-Alcalde, 1996) occur, especially Arduspirifer spp., Euryspirifer gr. pellicoi, Acrospirifer gr. fallax, and Plicanoplia carlsi. The brachiopod fauna would fit in the Leptaenopyxis kerfornei Faunizone (Racheboeuf, and Yesou, 1988): such unit is ecologically similar to the French "Faune de Monstres" (Morzadec, et al., 1988), well known immediately prior to the F12 level of the Le Faou Fm. in Brittany. In the uppermost part of the Bañugues Fm. very important coral-stromatoporoid biostromes are developed. Tabulate and rugose corals of the "Cyathaxonia Fauna", very similar to those of the lower part of the Abadía Fm. referred to above, occur from the base of La Ladrona Fm. upwards. The BZE is also represented in the Asturo-Leonian Domain by a very important proliferation of trilobites. Several new species of Pilletina, Pseudocryphaeus, Metacanthina, Treveropyge, phacopids, and proetids occur there (Arbizu, 1977; Smeenk, 1983; Truyols, et al., 1990; García-Alcalde, 1995). Dacryoconarids (Nowakia cf. acuaria, N. cf. zlichovensis, and Styliolina sp.) appear for the first time in Asturo-Leonian successions.

The above lithologic and faunal data enable us to correlate the BZE in other Spanish areas. The sandstone-limestone transition in the upper part of the Cercadillo Fm. in eastern Guadarrama (Figure 1), and in the Santa Cruz (d3)/Mariposas (d4) Fms. boundary (Figure 2) in Celtiberia (Figures 1,2) at the Polygnathus dehiscens (or $P$. excavatus) Zone, would correspond to the event (García-Alcalde, 1992). The brachiopod fauna has large forms close to those of the French "Faune de Monstres" cited above in Faunal Interval 8 (García-Alcalde, 1996), especially Euryspirifer pellicoi, Vandercammenina spp., Leptaenopyxis gr. kerfornei, and Acrospirifer gr. fallax. Arduspirifer spp. proliferate from the transition upwards, although the genus begins earlier. Philippotia belairensis and Plicanoplia carlsi occur from the topmost Santa Cruz Fm. upwards (Racheboeuf, 1981; Jahnke, et al., 1983). Trace-fossils (Zoophycos) are also abundant in the upper part of the Santa Cruz Formation (Carls, 1988).

The BZE could also be represented in the sandstone/shale to limestone transition between the Risquillo and Herrera Formations in the southern Central-Iberian Zone (Pardo-Alonso, and GarcíaAlcalde, 1996). Biostratigraphic indexes are scarce. but Euryspirifer gr. pellicoi and several forms of the genus Arduspirifer occur there from the base upwards, and Acrospirifer fallax, Pleurodictyum cf. problematicum, Combophyllum marianum, Adradosia barroisi and other "Cyathaxonia Fauna" elements are also known in the lower part of the Herrera Fm.

The Palentine faunas cited above are amazingly similar to those of the uppermost part of the Le Faou Fm. in the Rade of Brest (Brittany, France) (Figures 1, 2), constituting the so-called "first Hercynian incursion into Rhenish faunas of the Lower Devonian of the Armorican Massif" (Le Menn, et al., 1976). Thus level F12 of the Le Faou Fm. would represent the BZE in Brittany. The BZE could also be represented at the top of the Montguyon Fm. where similar Odontochile and brachiopod faunas have been reported at the Polvgnathus dehiscens Zone (Racheboeuf, 1981: Morzadec, et al., 1988: Gourvennec, 1989). The occurrence of phosphatic nodules associated with the BZE in the Armorican Massif has been attributed to a marine transgression (Le Menn. et al.. 1976).

\section{Upper Zlichovian Event (UZE)}

Even if the BZE is a very important geological marker in Spanish Devonian sections, as indicated by relatively abrupt lithologic and biologic change everywhere, it would not be the most important Zlichovian marker, at least in off-shore facies areas. That distinction goes to the so-called Upper Zlichov Event (UZE), herein. The UZE is probably coupled with one of the minor transgressive pulses of the Johnson, et al. (1985) global T-R cycle Ib (T-R cycle Ib3, herein), slightly older than the important Dalejan transgression (T-R cycle Ib4, herein) (Figure 2). Lithologic change at the UZE is usually not very distinctive but the biostratigraphic signature is profound. It includes the first significant radiation of non bactritid ammonoids, a major new animal group of high taxonomic level, soon to be a critical tool for Devonian biostratigraphy. The ammonoids appeared at the Nowakia zlichovensis Zone (in terms of the conodont scale, upper part of the Polygnathus dehiscens Zone). After rapid evolution from gyroconic to advolute forms. the ammonoids set this last shell 
coiling pattom. become abundant, and tinally reach completely coiled forms as Minagoniatites at the Polygnathus gronbergi and $N$. borramdei Zones (Becker, and House, 1994b). According to available biostratigraphic information, the first Erbenoceres-Mimagoniatites association seems to occur synchronously and worldwide, or nearly so, and thereby would be the most suitable UZE index. The rapid stepwise evolution through the Zlichovian to the Dalejan resulted in proliferation of many new, sometimes bizare, forms, the so-called "Anetoceras Fauna" (Chlupac, 1976).

In Palencia, the nost suitable, although admittedly weak, lithoevent for the ULE could be the ransition from the Requejada Lst Member to the overlying "Vanes beds" (Figure 2). The uppermost part of the Requejada Mb. comprises mudstones and bioclastic wackestones and packstones with hummocky and ripple cross bedding. The "Vañes beds" however is a ca. $19 \mathrm{~m}$ thick rhythmic sequence of alternating yellowish weathered, nodular or pseudonodular. sometimes bioturbated mudstones, wackestones and bioclastic packstones with hummocky cross bedding at the bottom and ripple cross bedding upwards, and interbedded grey, very fossiliferous, calcareous siltstones and shales (García-Alcalde, et al., 1990). Erbenoceras filalense and Mimagoniatites tabuliformis, the thrst Palentine representatives of the Aneteceres Fauna, occurs ca. 2-3 m. above the Requejada Mb. in the upper part of the Nowakia barrandei Zone. A single whorl fragment of Celaeceras sp. has been found also at the Nomakia barrandei Zone. Species of Mimagoniatites. Mimosphinctes, and Celaeceras occur higher. These forms range up to near the top of the "Vañes beds" across the topmost $N$. barrandei, $N$. elegans and basal N. cancellata Zones within the Polygnathus gronbergi Zone (Montesinos, and Truyols-Massoni, 1987: GarcíaAlcalde, et al. 1990; Montesinos, 1991; Montesinos, and GarcíaAlcalde, 1996). Orthocone nautiloids and phacopid trilobites are abundant. Tabulate and rugose corals of the Cvathaxonia Fauna are quite common but less diverse than in previous beds. Impoverished brachiopod faunas mainly of off-shore facies occur (Miniprokopia of. Mriconcha. Clorinda sp. Lissatrypa sp., and Philippotia sp.) (García-Alcalde et al., 1990).

In the Asturo-Leonian Domain, identification of the UZE depends on indirect comparison based on conodonts and scanty occurtences of nowakids (García-López, and Arbizu, 1993; GarciaAlcalde, and Truyols-Massoni. 1994: García-López, and AlonsoMenéndez. 1994; Truyols-Massoni and García-Alcalde, 1994). The UZE can be recognized there from a modest brachiopod radiation (Faunal Interval 9: Garcia-Alcalde. 1996). mainly characterized by the tirst appearance of Tetratomia gr. amanshauseri. Nucleospira cf. sirael. Spinatrya aff. orba, Resserella sp. D. Tyersella tetragona, Stenorhynchia briceae, Boucotstrophia velica, and Asturistrophia insolita; Schi-ophoria valvaria, Meganteris archiaci, Septathyris cf. davousti, Euryspirifer pellicoi, Plicostropheodonta diffusa. Mesoleptostrophia explanata, pleurodictyid tabulates and skeletal fragments of homalonotids are quite abundant. Viriatellina ef. hercynica and $V$. ef. gracilistriata, together with Nowakia sp., are also present. The UZE would thus coincide very closely to the Lower Emsian/Upper Emsian boundary as discussed in García-Alcalde, and Truyols-Massoni (1994) and in Truyols-Massoni, and GarciaAlcalde (1994). The related UZE litho-event would be a relatively important dark shale intercalation in the lower half of the La Ladrona and correlative Leonian Formations (Figure 2). In León, ca. $20 \mathrm{~m}$. above the supposed UZE level, Nowakia cancellata and conodonts of the Polygnathus laticostatus Zone occur (García-Alcalde, and Truyols-Massoni, 1994; García-López. and Alonso-Menéndez, 1994; and unpublished data on the range of $N$. cancellata in the La Vid section, from bed $30 \mathrm{c}$ upwards. Truyols-Massoni. pers.com.)

In Celtiberia, Anetoceras sp. and Minagoniatites of. zorgensis co-occur in the Mariposas Fm. (at the top of the d4bo subdivision; Carls, 1988) (Figure 2). Such ammonoid association seems a little younger than the Palentine "Anetoceras Fauna", because the upper half of d 4 bo yields abundant Nowakia elegans (Truyols-Massoni, pers.comm., based on samples of J. L. García-Alcalde). A more suitable level for the UZE could be the $\mathrm{d} 4 \mathrm{a} / \mathrm{d} 4 \mathrm{~b} \alpha$ transition (Figure 2) at the Polygnathus gronbergi Zone because in the uppermost part of the dtay subdivision several forms of García-Alcalde's Faunal lnterval 9 (Resserella sp. D. Spinatrypa orba, "Uncinulus pila". Thersella tetragona, and Sathophoria bularia) occur' author"s unpublisheddata).

In the Dra Plains (Anti-Atlas, Moroco). "Anetoceras adrot rens" (recto Erbenoceras fildeme'). Mimosphictes cantabricus, Devonodontochile maceovi. Spinodontochile spinifera, and othe? interesting forms occur (Hollard's "Faune 1", 1978. Tab. 2; see also Bultynck, and Hollard. 1980), at the lower part of the Oui n' Mesdour (western Dra) or Mdabuer El Kbir (eastern Dra) Formations. "Fauna I" directly overlies heds in the uppermost part of the Mer/a Akhsai Fm. with an abundant and characteristic brachiopod fauna closely similar to that of the "Faune de Monstres" referred to above and to that of the basal part of the Faunal Interval 8 (García-Alcalde. 1996). In these beds large forms of Emrapirifer ct pellicoi, A crospirifer gr. fallax, Vandereammenina trigeri. Mesoleptestrophia eyplantha.

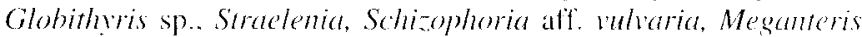
gr. archiaci, Iridistrophia sp.. and small Xana bubo. Uncimulus gr. pila, Stenorhynchia subpareti. Celtanoplia aulerciana. Renandia cf. maine'nsis, Plobejochonetes buchoti and other Ardenno-Rhenish brachiopods oceur. These biostratigraphic markers enable us to suggest:

1) The BZE would be placed around the abrupt sandstonc/limestone lithologic transition between the Mer/at Akhsai and overlying Dra Plains Formations. According to Bultynck and Hollard (1980) such level would correspond to the Polgghathus de/hiscens Zone. The occurrence of phosphatic pebbles in the uppermost part of the Merzal Akhsai Fn. has been interpreted as indicating a stratigraphic gap or condensed sedimentation (Hollard. 1978). but it coukt aho reflect a transgressive phase as in the Amorican sections lsee above).

2) The UZE would be placed at the occurrence of black to dark limestone layers in the lower (but not in the lowermost) part of the correlative Oui n'Mesdour and Mdaouer El Kbir Formations. According to Bultynck, and Hollard (1980), the lirst ammonoids (Erbenoceras filalense) occur at the Polygnathas dehise'ns/P. gronbergi Zone boundary, associated with upper Zlichovian dacryoconarids.

\section{Daleje-Cancellata Event (DCE)}

The DCE (Walliser, 1984, 1995; House, 1985; Becker, and House, 1994 ) is a rather peculiar Devonian event. It is recognized half way of a transgressive period (T-R Ib; Johnson, et al., 1985) that began much earlier, perhaps at the beginning of the Emsian Stage in its current definition. The coupled lithologic change is therefore usually observed to be quite gradual. The faunal change appears also very gradual, so that the faunal turnover should be appreciable only after a certain time interval (Walliser, 1984; Chlupáč, and Kukal, 1988). But, despite these apparent constraints the DCE is one of the Devonian events most broadly recognized worldwide. The age and the duration of the Event has been variably interpreted. Carls (1988). Chlupác (1995, text-figure 4) and Walliser (1995) regard it as a Zlichovian-Dalejan process: according to Carls (1988) the event lasted a timespan equivalent to the Nowakia elegans, $N$. cancellata, and $N$. richteri dacryoconarid Zones (Polygnathus laticostatus plus the lower part of the $P$. serotinus conodont Zones), whereas according to Chlupác (1995) and Walliser (1995) it overlaps the N. harrandei and the $N$. cancellata Zones (at the $P$. nothoperbonus and $P$. laticostatus Zones). According to Becker, and House (1994, text-figure 9) the DCE would strictly be Dalejan, overlapping the $N$. cancellata- $N$. richteri (Polygnathus laticostatus-P. serotinus Zones). I agree with the former authors in that the DCE is a Zlichovian/Dalejan event. However, as interpreted here, the event would be restricted to the first clear onset of black shales, coupled to the relatively more marked T-R Ib4 deepening pulse (Figure 2); that is to say, the DCE would be limited to the uppermost $N$. elegans and $N$. cancellata Zones (P. laticostatus Zone). 
In northern Spain, as in many Bohemian sections the DCE is characterized by the gradual takeover of dark to black shales from limestone and marly rocks at the Zlichovian-Dilejan boundary. The paleontological indexes, Nowakia elegans and $N$. cancellata usually appear at the levels where shales start to dominate over limestones. At the same beds or a bit higher, García-López, and Alonso-Menéndez (1994) have found in Leon conodonts of the Polvgnathus laticostatus Zone. Grötsch (1988) cited also P. laticostatus, in the La Vid Group, in León, at the base of his Esla Fm. (upper part of the unit 2 of the La Vid Group) (Figure 2), but the systematic assignment is discussed by García-López, and Alonso-Menéndez (1994).

In the Palentine Domain, the DCE is recognized at the top of the "Vañes beds" (Figure 2) around the Nowakia eleganis/N. cancellara Zone boundary. Conodonts are not known at this level: the more closest conodont fauna comes from the middle part of the "Vanes beds" at the $N$. elegans Zone, and might correspond to the uppermost $P$. gronbergi Zone (García-Alcalde, et al., 1990). The loosely coiled Erbenoceras and Minosphinctes, Mimagoniatites erbeni and the complex-sutured Celaeceras end before the $N$. elegans/N. cancellata Zone boundary (Montesinos, and Truyols-Massoni, 1987; Montesinos, 1991: Montesinos, and García-Alcalde, 1996). Gyroceratites, represented by a local species, $G$. pallantiamum, occurs higher in the pure shaly facies of the upper Abadía Fm. ca. 12-15 m. above the first occurrence of $N$. cancellata, and associated with Mimagonianites gr. fecundus (Montesinos, and Truyols-Matsisoni, 1987; Montesinos, 1990). Because of the general scarcity of fossils other than dacryoconarids in the pure shaly facies of the Abadia Fm.. other faunal markers for the DCE are lacking.

The DCE is readily recognizable in the Asturo-Leonian Domain, both in León, as indicated above, and in Asturias (GarciaAlcalde, 1992; García-Alcalde, and Truyols-Massoni. 1994; Truyols-Massoni, and García-Alcalde, 1994). The massive onset of fine siliciclastic sediments that indicates the deepening event, prevented the occurrence of abundant benthonic faunas, and the nectonic and planctonic ones are also scanty. The faunal change was quite gradual and marked by the occurrence of some new species rather than by the demise of the precedent ones. As interpreted here. such change occurred in beds younger than the BCE climax, belonging to the Faunal Interval 10 (García-Alcalde, 1996). Thus, in thin bioclastic limestone lenses of the Nowakia cancellata Zone the succesive appearance of brachiopods of mixed affinities as Crinistrophia cf. elegans, Aesopomum n. sp., Reticulariopsis of. indifferens. Straelenia ef. Iosseni, Triathyris n. sp. A, Brachyspirifer aff. carinatus, "Uncinulus suborbignyanus", Arduspirifer (Arduspirifer) latronensis, Plicathyris collensis, Protodonvillina kaeniolata, Anathyris phalaend and Struveina ferronesensis is prominent. A similar brachiopod change is recorded at the upper half part of the Mdaouer El Kbir Fm. in the eastern Dra Plains (Moroceo) (Hollard, 1978, and author's data), from the Polvgnathus laticostatus Zone upwards. The deepening event related to the DCE is very clear in the condensed sequences of the eastern Anti-Atlas region ( $B$ ou Tchrafine and Hamer el Khdad. Tatilatt). In the Bou Tchrafine sections a few meters (usually less than $2 \mathrm{~m}$ ) above dark to black limestones with ammonoids of the "Anetoceras Fauna" (Erbenoceras filalense and others), thin-bedded marly nodular limestones and interbedded dark calcareous shales of the Nowakia elegans-N. cancellata Zones are found. This level represents the DCE in the region, although other faunal indexes are not as yet well known. In the Hamer el Khdad region. the Lower Emsian successions are developed on the famous "Kess-Kess" (bioclastic wackestones and packstones mud mounds) (Brachert et al., 1992). In this region, the DCE is recorded at the top of the Kess-Kess and represents the end of these peculiar bioclastic accumulations. In both regions, the beginning of the main Dalejan deepening phase, represented by the onset of dark to black shales with sparse mudstone nodules is recorded a few meters above the first occurrence of $N$. cancellata (Alberti. 1980), and author's unpublished data).

As quoted above, Carls (1988) interpreted the DCE in Celtiberia as coupled to the entire phase of pelagic shaly facies deposition from the base of the $d 4 b \beta$ submember of the Mariposas Fm. (and correlative units in Guadarrama) (Figure 2) upwards, at the Polygnathus laticostatus plus the lower part of the $P$. serotinus Zones, and Nowakia elegans to N. richteri Zones This author emphasizes also the remarkable similarity of the DCE development every where although minor differences can occur.

More work is required to identify precisely the DCE in the Armorican Massif (France). The range of index fossils, as Nowakia elegans or $N$. cancellata is not yet well known. Moreover outcrops are usually poor and very tectonized at the critical levels. The available information in the Rade of Brest indicates the best interval to investigate the event could be at the transition between the Reun ar C'Hrank and Beg an Arreun Fms. (Figure 2). Inmediately prior to this level. typical Upper Emsian trilobites, such as Rhenops lethacae, and dacryoconarids as Nowakia cf. zlichorensis occur. And ca. 8-10 m. above the base of Beg an Arreun Fm., Uncinulus suborbignyanus and conodonts of the Polygnathus laticostatus Zone have been found (Bultynck and Morzadec, 1979). Nowakia cancellata occur at the upper part of the Beg an Arreun Fm. (Morzadec. 1983), probably high in their normal stratigraphical range.

\section{Chronostratigraphical remarks}

Recent chronostratigraphic developments makes precise dating of the BZE difficult. The Pragian/Emsian (P/E) boundary definition, related to the incoming of Polygnathus dehiscens or the closely related but perhaps older P. kitabicus (Yolkin, et al., 1994) is unfortunate. Objections concern the problematic identification, even by specialists, of conodonts of the $P$. pireneat- $P$ dehiscens lineage (Mawson, 1995), lack of elear auxiliary means for identification of the P/E boundary (Chlupác, 1995), and drastic reduction, after the new definitions, of the original scope of the Pragian and Siegenian Stages (Carls, and Valenzuela-Ríos, 1993; Chlupáč, 1995). Apart from differences in the assessment on what must be regarded as "classic Siegenian or Emsian" (García-Alcalde, 1992: contra Carls, 1987. 1988; Carls, and Valenzuela-Ríos, 1993: Weddige, 1996), the P/E kitubicus boundary appears considerably older than the lowest Zlichovian and thereby than the BZE.

Mawson (1995) has vigorously confronted the biostratigraphic "revolution" involved in Yolkin et al's (1994) proposals. That author considers the holotype of $P$. kitabicus to be a large specimen of $P$. pireneate, and in the other hand $P$. excavatus to be a junior synonyme of $P$. dehiscens. If these assertions should finally be agreed the " $P$. dehiscens" Pragian/Emsian boundary would return to a closer stratigraphic position to the BZE as suggested by GarcíaAlcalde (1992, 1996) and Garcia-Alcalde, et al. (1997) and the takeover of Pragian beds in the Emsian would therefore be less substantial than reported by Chlupác (1995). The proximity of such events, the BDE and the incoming of $P$. dehiscens, appears indeed clear in castern Guadarrama (Central Spain). There, the onset of transgressive carbonate rocks related to the BZE at the top of Member 7 of the Cercadillo Fm. (Bultynck, 1979) occurs at the upper part of the P. kitabicus zone (sensu Yolkin, et al. 1994) and therefore close to the base of the $P$. dehiscens ( $P$. excalatus) Zone according to the occurrence of Polygnathas forms close to "P. excavatus", and $P$. pannonicus (Bullynck, pers. comm.).

In any case a joint conodont revision of the P.pireneute-P. dehiscens lineage by specialists and final agreement are badly need to resolve these important stratigraphic topics. As such, Mawson's proposal to go back to SDS for re-definition of the base of Emsian seems logical.

The occurrence of rather distinct faunal turnover in both the Lower Emsian/Upper Emsian and Zlichovian/Dalejan boundaries in their respective type areas has usually been interpreted as recording a single. perhaps global event and thereby the equivalence of both substage boundaries has oftenly been asserted. Nevertheless. many authors have suggested the base of the Upper Emsian would be a bit older than the base of Dalejan (Lütke, 1979; Morzadec, 1983; Morzadec, et al., 1988; García-Alcalde, and Truyols-Massoni, 1994; 
Truyols-Massoni. and García-Alcalde. 1994: among other). From the above discussion it appears both levets are tied to close but separated events. respectively the UKE and the DCE. Therefore the interval between the UZE level and the first occurrence of Nowakia cancellata, would be the best stratigraphic horizon to choose a redefined Lower Emsian/Upper Emsian boundary stratotype. The Faunal Interval 9 (García-Alcalde. 1996) would be an outstanding auxiliary fossil sequence in approaching this re-definition in the Western Europe near-shore facies realm. Concerning to the conodont biostratigraphy, the UZE occurs in the $P$. gronbergi Zone. A possible subdivision of that zone based in more precise studies on the $P$. perbonus, $P$. nothoperbonus and $P$. gronbergi ranges, could perhaps provide the necessary fossil-guides to international correlation. In the other hand, the Dalejan, the $N$. elegans/ $N$. cancellata boundary and the DCE have repeatedly been related with the incoming of $P$. laticostatus, but the range of this species is not yet well known because it is regarded alternatively as older and as younger than the base of Dalejan (Truyols-Massoni, and García-Alcalde, 1994). The revision of the $P$. laticostatus lineage would therefore be another unavoidable goal for the conodont specialists.

\section{Acknowledgments}

This study is a contribution to the basic research project of the Dirección General de Investigación Científica y Técnica (DGICYT), Spain, PB-94/1324 "Eventos geo-biológicos en el Devónico del Macizo Ibérico (España)" and IGCP 421 "North Gondwana MidPalaeozoic Bioevent/Biogeography patterns in relation to crustal dynamics". Many thanks are due to Miss Heather Stoll who has greatly improved the English text.

\section{References}

Alberti. G K B, 1980. Neue Daten zur Grenze Unter Mittel-Devon, vornehmlich aufgrund der Tentaculiten und trilobiten im Tafilalt (SE-Marokko). Neues Jahrbuch Geologie Paläontologie Mh., v. 1980, no.10. pp. $581-594$.

Arbizu. M, 1977. Asteropyginae (Trilobita) du Devonien des Montagnes Cantabriques (Espagne). Bulletin Societe Geologique et Mineralogique de Bretagne: s. C. v. 9. no. 2. pp. 59-102

Becker. R.T. and House, M.R. 1994, International Devonian goniatite zonation, Emsian to Givetian. with new records from Morocco. Courier Forschungsinstitut Senckenberg. v. 169. p. 79-135.

Brachert. T C. Buggisch. W. Flügel, E. Hüssner, H M. Joachimski. M M Tourneur. E. and Walliser. O H, 1992. Controls of mud mound formation: the Early Devonian Kess-Kess carbonates of the Hamar Laghdad. Antiatlas, Moroceo: Geologische Rundschau, v. 81, no. 1, pp. 15-44.

Bultynck. P. 1979. Excursion in the Devonian of the Sierra de Guadarrama between Cercadillo and La Riba de Santiuste, in García-Alcalde, J L. Arbizu. M A. García-López, S, and Méndez-Bedia. I eds, Meeting of the International Subcommission on Devonian Stratigraphy. Guidebook of the field trip: Servicio de Publicaciones de la Universidad de Oviedo, pp. $32-34$.

Bultynck. P. and Hollard, H. 1980. Distribution comparée de Conodontes et Goniatites dévoniens des plaines du Dra, du Ma'der et du Tafilalt (Maroc): Aardkundige Mededelingen, v. 1, pp. 1-73.

Bultynck. P, and Morzadec, P, 1979, Conodontes de la coupe de Reun ar C'Hrank en Lanvéoc (Rade de Brest) Emsien du Massif Armoricain (France) Corrélations biostratigraphiques: Geobios, v. 12, no. 5. pp. $675-685$

Carls, P. 1987, Ein Vorschlag zur biostratigraphischen Redefinition der Grenze Gedinnium/Siegenium und benachbarter Unter-Stufen. Stratigraphische Argumente und Korrelationen: Courier Forschungsinstitut Senckenberg, v. 92. pp. 77-121.

Carls, P, 1988, The Devonian of Celtiberia (Spain) and Devonian paleogeography of SW Europe. in: McMillan. N J, Embry. A F, and Glass, D J eds. Devonian of the World: Memoirs of the Canadian Society of Petroleum Geologists, v. 14, no. 1, pp. 421-466.

Carls, P, and Valenzuela-Ríos, J I, 1993, Materials near the redefined base of the Emsian stage: Newsletter of the Subcommission on Devonian Stratigraphy, v. 10, p. 30 .
Chlupac, I. 1976. The oldest goniatite faunas and their stratigraphical significance: Lethaia, v. 9, pp. 303-315

Chlupač, I, 1994, Devonian trilobites-evolution and events: Geobios. v. 27. no. 4, pp. 487-505.

Chlupač. 1. 1995. Evaluation of Some Devonian Standard Boundaries. Nova Acta Leopoldina NF, v. 71, no. 291, pp. 41-52.

Chlupač I. and Kukal, Z. 1986. Reflection of possible global Devonian events in the Barrandian area, C.S.S.R.. in Walliser. O ed, Global Bio-Events. A critical approach: Lecture Notes in Earth Sciences, v. 8. pp. 169-179.

Chlupač I, and Kukal, Z. 1988. Possible global events and the stratigraphy of the Palaeozoic of the Barrandian (Cambrian-Middle Devonian. Czechoslovakia): Sbornik geologickych Ved. Geologic. v. 43. pp. 83-146.

García-Alcalde. J L. 1992. El Devónico de Santa Maria del Mar (Castrillón. Asturias. España): Revista Española de Paleontología, v. 7. no. 1, pp. 53-79.

García-Alcalde. J L, 1995. L'evolution paleogeographique pre-Varisque de la Zone Cantabrique septentrionale (Espagne): Revista Española de Paleontologia, v. 10, no. I. pp. 9-29.

García-Alcalde. J L, 1996, El Devónico del Dominio Astur-Leonés en la Zona Cantábrica ( $\mathrm{N}$ de España): Revista Española de Paleontología, no. extraordinario, pp. 58-71

García-Alcalde, J L, Arbizu, M, García-López, S, Leyva. F, Montesinos, R, Soto, F. and Truyols-Massoni, M, 1990. Devonian stage boundaries (Lochkovian/Pragian. Pragian/Emsian, and Eifelian/Givetian) in the Cantabric region (NW Spain): Neues Jahrbuch Geologie Paläontologie Abhandlungen. v. 180 , no.2, pp.177-207.

García-Alcalde, J L, and Truyóls-Massoni. M. 1994. Lower/Upper Emsian versus Zlichovian/Dalejan (Lower Devonian) boundary: Newsletters in Stratigraphy, v. 30. pp. 83-89.

Garéa-Alcalde. J, L, Truyóls-Massoni. M. Pardo, M, Bultynck, P. and Carls, P. 1997. Devonian chronostratigraphy of Spain. Courier Forschungsinstitut Senckenberg (in press).

García-López, S, and Alonso-Menéndez, C, 1994. Conodontos del Grupo La Vid, limites Praguicnse/Emsiense y Emsiense Inferior/Emsiense Superior, Zona Cantábrica (NO de España): Revista Española de Micropaleontología, $\because .26$, no. 2, pp. 81-97.

García-Lópcz. S. and Arbizu. M. 1993. Nuevos hallargos de conodontos en el Devónico Inferior de la costa asturiana y su aplicación a la cronoestratigrafía del Grupo Rañeces: Revista Española de Paleontología. no. extraordinario, pp. 78-88.

Gourvennec. R. 1989. Brachiopodes Spiriferida du Devonien Inferieur du Massif Armoricain. Systematique-Paleobiologie-Evolution-Biostratigraphie.: Biostratigraphie du Paleozoique,v. 9, pp. I-155.

Grötsch. J, 1988. Conodonten und Stratigraphie der unterdevonischen La Vid Formation (Kantabrisches Gebirge, NW-Spanien): Erlanger geologie Abhandlungen, $v$.115, pp. 155-198.

Hollard. H. 1978. Correlations entre niveaux a brachiopodes et a goniatites au voisinage de la limite Dévonien inférieur-Dévonien moyen dans les plaines du Dra (Maroc présaharien): Newsletters in Stratigraphy. v. 7. no. l, pp. 8-25.

House, M R. 1985, Correlation of mid-Palacozoic ammonoid evolutionary events with global sedimentary perturbations: Nature. v. 313, pp. 17-22.

Jahnke, H. Henn, A, Mader, H. and Schweineberg, J. 1983. Silur und Devon im Arauz-Gebiet (Prov.Palencia. N-Spanien): Newsletters in Stratigraphy, v. 13, no. 1, pp. 40-66.

Johnson. J G. Klapper, G. and Sandherg. C. A, 1985. Devonian eustatic fluctuations in Euramerica: Geological Society of America Bulletin. v 96. pp. $567-587$.

Le Menn. J. Plusquellec,Y. Morzadec. P, and Lardeux. H. 1976, Incursion hercynienne dans les faunes rhenanes du Devonien inferieur de la rade de Brest (Massif Armoricain): Palacontographica. A, v. 153, no. 1-3, pp. $1-61$

Lütke, F, 1979. Biostratigraphical significance of the Devonian dacryoconarida, in House, M R, Scrutton. C T, and Bassett, M G. The Devonian System: Special Papers Palaeontology, v. 23. pp. 281-289.

Mawson, R, 1995, Early Devonian polygnathid conodont lineages with special reference to Australia: Courier Forschungsinstitut Senckenberg, $v$. 182, pp. 389-398.

Montesinos, J R, 1990, Las biozonas de ammonoideos del Devónico (Emsiense inferior-Famenniense inferior): crítica al sistema de clasificación zonal: Revista Española de Paleontología, v. 5. pp. 3-17.

Montesinos. J R, 1991, Ammonoideos de las Capas de Vañes (Formación Abadía, Devónico Inferior) del Dominio Palentino (Palencia. NO de España): Cuadernos Laboratorio Xeoloxico de Laxe, v. 16, pp. 193-201.

Montesinos, J R, and García-Alcalde. J L, 1996. An occurrence of the Auguritid ammonoid Celaceras in the Lower Devonian of northern Spain: Palaeontology, v. 39, no. 1, pp. 149-155. 
Montesinos, J R, and Truyóls-Massoni, M, 1987. La Fauna de Anetoceras y el límite Zlichoviense-Dalejiense en el Dominio Palentino (NO de España): Cuaderno do Laboratorio Xeoloxico de Laxe, v. 11, pp. 191-208.

Morzadec, P, 1983, Le Dévonien (Emsien-Famennien) de la rade de Brest (Massif Armoricain). Lithologie, cartographie, stratigraphie, paléogéographie: Geologie de la France, v. 2, no. 4, pp. 269-310.

Morzadec, P, Paris, F, Plusquellec, Y, Racheboeuf, P, and Weyant, M, 1988 Devonian stratigraphy and paleogeography of the Armorican Massif (western France), in: McMillan, N J, Embry, A F, and Glass, D J eds, Devonian of the World: Memoirs of the Canadian Society of Petroleum Geologists, v. 14, no. 1, pp. 401-420.

Pardo-Alonso, M.V. and García-Alcalde, J L, 1996, El Devónico de la Zona Centroibérica. Revista Española de Paleontologia, no. extraordinario, pp. $72-81$.

Racheboeuf, P R, 1981, Chonetacés (Brachiopodes) siluriens et dévoniens du sud-ouest de l'Europe: Memoires de la Societe Geologique et Mineralogique de Bretagne, v .27, pp. 1-294.

Racheboeuf, P R, and Yesou, H, 1988, La Formation du Faou (Devonien Inferieur du Finistere): nouvelles observations biostratigraphiques et mise en evidence d'une ecozone: Geobios, v. 21, no. 1, p. 41-47.

Smeenk, Z, 1983, Devonian trilobites of the southern Cantabrian Mountains (Northern Spain) with a systematic description of the Asteropyginae: Leidse Geologische Mededelingen, v. 52, no. 2, pp. 383-511.

Soto, F, and Kullmann, J, 1996, Hornförmige Eizelkorallen (Rugosa) vom Typ der "Cyathaxonia-Fauna" im Unter-Emsium des östlichen Kantabrischen Gebirges, NW-Spanien: Geobios, v. 29, no. 6, pp. 651-669.

Truyols, J, Arbizu, M A, García-Alcalde, J L, García-López, S, MéndezBedia, I, Soto, F, and Truyols-Massoni, M, 1990, The Asturian-Leonese Domain (Cantabrian Zone), in Dallmeyer, R D, and Martínez-García, E eds, Pre-Mesozoic Geology of Iberia, Springer, pp. 10-19.

Truyols-Massoni, M, and García-Alcalde, J L, 1994. Faune rhéno-bohemienne (Dacryoconarides, Brachiopodes) à la limite Emsien inférieur/supérieur au Cabo La Vela (Asturies, Espagne): Geobios, v. 27, no. 2, pp. 221-241.

Walliser, $\mathrm{OH}, 1984$, Geologic processes and global events: Terra Cognita, v. 4. pp. $17-20$.

Walliser, O H. 1995, Global Events in the Devonian and Carboniferous, in Walliser, O H ed, Global Events and Event Stratigraphy in the Phanerozoic, Springer, pp. 225-250.

Weddige, K, 1996, Devon-Korrelationstabelle.: Senckenbergiana lethaea, v. 76, no. $1 / 2$, pp. 267-286.

Yolkin, E A, Weddige, K, Izokh, N G, and Erina, M V, 1994, New Emsian conodont zonation (Lower Devonian): Courier Forschungsinstitut Senckenberg, v. 168, pp. 139-157,

\section{García-Alcalde is Professor of Paleontology at the Department of Geology, University of Oviedo, Spain. He holds currently the posi- tion of Second Director at the Department of Geology. He has recently been appointed Associate Editor of the new review Palaeonto- logica Electronica. He is Titular Member of the Subcommision on Devonian Stratigraphy from 1989. His research interests are Devonian events, paleobiogeography, and bio- stratigraphy, with special emphasis on brachiopod taxonomy and bio- stratigraphy.}

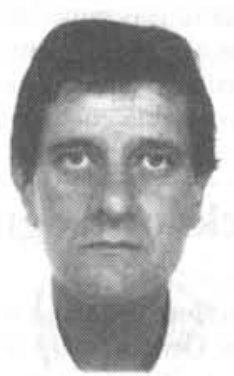

\title{
Episodes CALLS FOR PAPERS
}

Episodes is the quarterly science and news journal of the International Union of Geological Sciences (IUGS). It focuses on the publication of results of scientific research and other information addressing issues of interest to the global earth-science community. Special emphasis is given to topics involving geological aspects of population growth and economic development and their resulting impacts on or implications for society. As the principal publication of the IUGS, Episodes also carries information about IUGS scientific programs and activities to the extent necessary to communicate effectively with the worldwide IUGS constituency.

Contributions of the following types of manuscripts are here solicited:

- scientific articles

- conference reports

- news and views

- letters to editor

- book reviews

- information on training courses (especially those geared to participants from developing countries)

- noteworthy new publications, including national or regional geologic maps

Episodes also invites photos or other images for the front cover. Photos must be of high technical quality and tell an interesting geological story. A color transparency and one color print (at least $9 \mathrm{~cm} \times 12.6 \mathrm{~cm}$ ) are required for submission, which should be supplemented with a short explanatory paragraph (no more than 100 words).

Please address all contributions to:

\author{
The Editor \\ Episodes \\ P. O. Box 823, 26 Baiwanzhuang Road \\ 100037 Beijing, CHINA
}

Tel: +86-10-68320827; Fax: +86-10-68328928; E-mail: Episodes@public.east.cn.net 